\title{
FORMATION OF PALM OIL CULTIVATION IN PARA'S AMAZON
}

https://doi.org/10.4215/rm2020.e19007

João Santos Nahum ${ }^{*}$ - Leonardo Sousa dos Santos ${ }^{b}$ - Cleison Bastos dos Santos c

(a) Dr. em Geografia. Professor da Universidade do Pará, Belém (PA), Brasil.

ORCID: https://orcid.org/0000-0001-7791-9240. LATTES: http://lattes.cnpq.br/9009465125001273.

(b) Doutorando em Geografia da Universidade do Pará, Belém (PA), Brasil.

ORCID: https://orcid.org/0000-0003-1912-7100. LATTES: http://lattes.cnpq.br/8784955066806824.

(c) Doutorando em Geografia da Universidade do Pará, Belém (PA), Brasil.

ORCID: https://orcid.org/0000-0001-6190-0705. LATTES: http://lattes.cnpq.br/2064008446923329.

\author{
Article history: \\ Received 25 October, 2019 \\ Accepted 02 February, 2020 \\ Publisher 15 March, 2020
}

\section{(*) CORRESPONDING AUTHOR}

Address: Rua 2 de Junho, Conj. Jardim Amazônia II, Qd.13.Casa 18. Águas Brancas. Ananindeua (PA). CEP: 67033-215.

E-mail: prof.joaonahum@gmail.com

\section{Abstract}

The formation of palm oil cultivation in Para's Amazon has as guide the state action. Emphasizing that the state makes possible the arrival of palm oil, encourages business creation through programs, projects and policies. The process of reconstituting milestones on origin, consolidation and expansion, which goes from the 1950s to the second decade of the 21 st century, was based on the vast literature review on the topic, data collection about palm oil cultivation, palm oil production, emergence, merger, business extinction and the situation of family farming integration projects. Th first part of the text focus on the arrival of oil palm in the Amazon, next, has highlight the creation of palm oil companies and finally analyze palm oil policies. This explains the distribution of the crop predominantly by the Tomé-açu microregion and the current period marked by the projects of integration of rural farmers into the palm oil agribusiness chain, through the discourse of rural territorial development with social inclusion, and job and income generation.

Keywords: Palm oil, State, Politics, Territory, Amazon.

\section{Resumo / Resumen}

\section{FORMAÇÃO DA DENDEICULTURA NA AMAZÔNIA PARAENSE}

A formação da dendeicultura na Amazônia paraense tem como fio condutor a ação estatal. Ressalta-se que o Estado torna possível a chegada do dendezeiro, incentiva a criação de empresas, por meio de programas, projetos e políticas. O processo de reconstituição dos marcos sobre a origem, a consolidação e a expansão, que vai de a década de 1950 até a segunda década do século XXI, apoia-se na vasta revisão de literatura sobre o tema, levantamento de dados sobre cultivo do dendezeiro, produção de dendê, surgimento, fusão, extinção de empresas e a situação dos projetos de integração da agricultura familiar. A primeira parte do texto enfoca a chegada do dendezeiro na Amazônia; a seguir destaca-se a criação das empresas dendeicultoras e por fim analisa-se políticas para a dendeicultura. Isso explica a distribuição do cultivo predominantemente pela Microrregião de Tomé-açu e o período atual marcado pelos projetos de integração do agricultor rural à cadeia do agronegócio do dendê, através do discurso do desenvolvimento territorial rural com inclusão social e geração de emprego e renda.

Palavras-chave: Dendeicultura, Estado, Política, Território, Amazônia.

\section{FORMACIÓN DE LA DENDEICULTURA EN LA AMAZONIA PARAENSE}

La formación de la dendeicultura en la Amazonia paraense tiene como hilo conductor la acción estatal. Resaltamos que el Estado torna posíble la llegada del dendezeiro, incentiva la creación de empresas, por medio de programas, proyectos y políticas. El proceso de reconstitución de los hitos sobre el origen, la consolidación y la expansión, que va de la década de 1950 hasta la segunda década del siglo XXI, se apoyó en la vasta revisión de literatura sobre el tema, levantamiento de datos sobre cultivo del palma aceitera, producción de dende, surgimiento, fusión, extinción de empresas y la situación de los proyectos de integración de la agricultura familiar. La primera parte del texto enfocamos la llegada del palma aceitera en la Amazonia, a seguir destacamos la creación de las empresas dendeicultoras y por fin analizamos políticas para la dendeicultura. Eso explica la distribuición del cultivo predominantemente por la microregión de Tomé-açu y el período actual marcado por los proyectos de integración del agricultor rural a la cadena del agronegócio del dende, por medio del discurso del desarrollo territorial rural con inclusión social y generación de empleo y renta.

Palabras-clave: Dendeicultura, Estado, Política, Território, Amazonia. 


\section{INTRODUCTION}

In this analysis of the constitution of oil palm cultivation in the Amazonian region of Pará state, we emphasize that this geographical phenomenon has been planned and structured by state action. The corollary of this is the organization of rural space for the reproduction of capital and, consequently, the modification of the landscape, spatial configuration and social relations in the places where oil palm cultivation is established. It is a revealing dynamic of the dialogue between the political and spatial instances because without state plans and programs this rural activity would not have reached the status of an agribusiness.

For more than half a century the cultivation of the African oil palm (Elaeis guineenses jacq.) has been part of the rural productive space in the Paraense Northeast and has thus aroused analytical interest. Homma (2016) drew up a chronology of this process in the region starting with the crop's introduction and placing its evolution within the regional economic cycles, without grouping the various events into sets of indicators regarding the activity's new directions in Amazonia. In turn, Homma and Furlan Júnior (2001, p. 93) wrote about "the chronology of the various events that marked the economic history of the Amazon, the cycles of agricultural activities and the recent insertion of oil palm cultivation as forming a new economic sub-cycle". Carvalho and Nahum (2014, p. 14) characterized "the geographic period in which oil palm cultivation is inserted, thus proposing a periodization of oil palm cultivation in the state of Pará". These works focus on oil palm cultivation and enable its trajectory to be traced, marking the milestones, based on the prerequisites for analyzing spatial dynamics.

In this article, we seek to understand the formation of oil palm cultivation in the eastern Amazon, taking state action as the guiding thread. It is the State that made the introduction of the African oil palm possible and encouraged the creation of companies through programs, projects and policies; in short, it created the normative, financial and spatial conditions capable of promoting oil palm cultivation as a vector for rural territorial development. The first part of the text focuses on the arrival of the oil palm in the Amazon, then we highlight the creation of companies cultivating oil palm and finally, we analyze policies for oil palm cultivation.

This analysis helps to explain the crop's predominant distribution in the Tomé-Açu Microregion and clarifies the period marked by projects to integrate the rural farmer into the oil palm agribusiness chain, through a discourse of rural territorial development with social inclusion and job and income generation. This process of reconstituting the key points of the origin, consolidation, and expansion of the business is supported by a vast literature review on the topic. Data was collected on oil palm cultivation and palm oil production, as well as the emergence, merging and extinction of companies and the situation of the integration projects for family farming.

Furthermore, the study analyzes political actions and their repercussions for oil palm cultivation and its spatial organization, highlighting the impact of those periods singularized by particular policies. We start from the beginning of African oil palm farming until its transformation into large-scale oil palm cultivation, as a logic of spatial production associated with a form of subjectivity built by capital, enabled and disseminated by state/business action and introjected by family farmers and rural laborers, reproducing what Dardot and Laval (2016, p. 17) called a "generalization of competition as a norm of conduct and the company as a model of subjectivation". Such a rationale results from a market mentality, the only reason operating in human existence, dividing society into entrepreneurs, customers, employees, and consumers.

\section{FIRST STEPS}

The African oil palm (Guinean Elaeis Jacq.) reached the Amazon from the state of Bahia between the early 1940s and 1950s, encountering some variations in the optimal conditions that do not prevent the cultivation of the oil palm but which, according to Müller (1980), may reduce the crop's yield. These essential conditions include:

a) An average monthly temperature between 25 and $28^{\circ} \mathrm{C}$; b) an average monthly minimum temperature above $18^{\circ} \mathrm{C}$; c) well-distributed insolation over 1,500 hours per year; d) well-distributed rainfall above 2.000 
$\mathrm{mm}$ per year and a maximum of three months with less than $100 \mathrm{~mm}$; e) a flat topography with slopes less than $10 \%$ declivity; f) the physical structure of the soil must be deep and without compaction up to one meter from the surface [...] in terms of texture the preferred soils are those with between $20 \%$ and $30 \%$ of fine particles; g) the chemical composition of the soil: oil palm is quite tolerant in terms of chemical composition, but ideally, it should be rich in humus and have well-balanced nutritional elements (MÜLLER, 1980, p. 11-12).

Homma (2016, p.15) states that "Francisco Coutinho de Oliveira, head of the Lira Castro Agrarian Field of the Ministry of Agriculture" was one of those responsible for the introduction of this crop, through the importation of selected seeds from the Ivory Coast. The state pilot-project was born in the Superintendence of the Amazon Economic Valorization Plan (SPVEA). Homma's (2016) interpretation was that:

José Maria Pinheiro Conduru, from the Northern Agricultural Research and Experimentation Institute (IPEAN), is representative of the standpoint of the technical publications at the time. His work entitled "Oil palm cultivation has possibilities in the Amazon", recommends the cultivation of palm trees in the municipalities in the northern region. Conduru's (1957) work exemplifies the research that enabled investment in areas ecologically favorable to the cultivation of the African oil palm and the possibility of continuous production in the Amazon (HOMMA, 2016, p.17).

Oil palm cultivation was promoted by the State during the first ten years but remained in an embryonic stage until the following decade with Operation Amazon in 1966. According to Nahum (2011), Operation Amazon reinvented the Amazon as a frontier. A ministerial report presented to the President of the Republic for consideration by the Extraordinary Minister for the Coordination of Regional Organizations (MECOR) states

Art. 1. Operation Amazon is hereby instituted, with the primary purpose of mobilizing and coordinating government efforts that are oriented towards the development and reformulation of federal policy in the Amazon region, in order to update and give new priorities to development and occupation programs of the Amazon territory.

Art.2. Priority will be given to measures of a legislative nature and the regulation of executive tasks aimed at proposing amendments to current legislation, as well as the constitution of public and private bodies, according to the respective federal action articulation criteria, in the Amazon area (MECOR, [196?] p.2)

Among the measures were the transformation of the SPVEA into the Superintendence of Development of the Amazon (SUDAM) and the Banco de Crédito de Amazônia into Banco da Amazônia S / A (BASA), the implementation of the tax incentives policy, and land concessions. Since then, spatial dynamics in Amazonia cannot be understood without taking development plans into account. These plans established areas for rubber production, livestock and oil palm cultivation and allocated resources to the Amazon in order to "invent the region as an agricultural and agropastoral frontier" (MÜLLER; ALVES, 1997, p. 16). Ianni (1986) argues that it is at this point that the State, based on the ideology of the agricultural frontier, offered inducements for national and international capital to acquire land in the region, deepening the unequal regional agrarian structure and fomenting tensions, conflicts, violence, and murder in Amazonian agricultural space.

It is evident that the territorial planning proposed in Operation Amazon reorganized the landscape, spatial configuration, and social dynamics, in short, the whole regional space. In the 1960s, the State proposed a large-scale oil palm cultivation project in the Amazon whose goal was to create a palm oil production pole. During the so-called Brazilian economic miracle (1968/1973), oilseed cultivation projects were wrapped in a particular ecological, economic and social philosophy. At that time, publications indicated broadly favorable environmental conditions (FURLAN JÚNIOR et al., 2006) and evaluated African oil palm cultivation in the Amazon as promising. Homma (2016) views the research by José Maria Pinheiro Conduru, from the Northern Agricultural Research and Experimentation Institute (IPEAN), as representative of the leanings of the technical publications of this 
period.

Conduru (1957) analyzed the efforts that enabled investment in ecologically favorable areas for cultivation in the Amazon that could have continuous production. For Costa (2010), this might generate jobs and income for farmers. This ecological-economic-social philosophy drove the research, the technology transfer, the expansion of the irrigation infrastructure, the distribution of hybrid seeds (65 thousand seedlings and 160 thousand oil palm seeds), synthetic fertilizers and pesticides, and other actions to consolidate this activity in the North of Brazil (VILLELA, 2014; HOMMA; FURLAN JÚNIOR, 2001). An example was the transfer of technology by crossing the caiaue oil palm (P) from the Museu Paraense Emílio Goeldi, with the oil palm pollen ( $\overbrace{}^{\Uparrow})$ from Campo Agrícola Lira Castro (FURLAN; JÚNIOR, 2004; HOMMA, 2016).

In general, the birth, growth, and consolidation of oil palm cultivation in the Amazon was propelled by state action and within the scope of development planning that perceived rural space as an attractive sector for the economy of investors and investments. This conception of agricultural vocation has long been part of state action, exemplified in the 1930s by the march to the west (HOLANDA, 1986), being reissued in the 1970s in the colonization and agricultural frontier processes in the Amazon (LENÁ; OLIVEIRA, 1992 ). According to Almeida, Guimarães, and Rivero (2009), until 1967 the guidelines for oil palm cultivation were prepared by the Instituto Agronômico do Norte (IAN) and SPVEA, after which SUDAM's development plans promoted the activity. With these technical and spatial conditions in place the private sector entered the productive chain, financed by Banco da Amazônia, Banco do Estado do Pará and Banco do Brasil. Thus, year after year, new plantations have been established, consolidating the oil palm agribusiness in the Amazon of Pará

\section{OIL PALM COMPANIES}

Between 1956 and 1981, cooperatives and companies dedicated to oil palm cultivation and production were organized in the Amazon, attracted by the extensive anthropized area,

low labor costs, the absence of unionization among rural wage earners, the abundance of water bodies ensuring the water supply for plantations, and the beginning of the construction of highways, such as the Belém - Brasília (BR-230) giving easy access to communication and economic flows, among others (DIAS; SOUZA, 1973, p.10).

When implementing pilot projects, the State defined areas and supported small and medium-sized farmers in the acquisition of the inputs, technical assistance and bank credit necessary for planting (DIAS, DE SOUZA, 1973). A bidding process chose the company Indústria e Comércio de Fibras LTDA (Fibroco), which had extensive experience in agro-industrial cultivation and export, to execute the projects. However, the original project was developed by the Paris-based L'Institut de Recherches pour les Huiles et Oléagineux (IRHO), an internationally renowned entity researching oil palm cultivation, which operated from 1942 to 1984.

The first oil palm plantations in the northern region date from 1967 in the rural area of the municipalities of Castanhal, Santa Isabel and Santo Antônio do Tauá, members of pilot projects developed based on agreements between the State and IRHO (SANTOS, 2016).

In the following years, the municipality of Benevides had satellite plantations promoted by the Cooperativa Agrícola Mista Paraense (Cooparaense), representing the first commercial-scale cultivation (ENRÍQUEZ; SILVA; CABRAL, 2003). The Dendê do Pará (Denpasa), located near the city of Belém, is the oldest oil palm company in Pará and was built with SUDAM tax incentives and opened in 1975.

The implementation of the pilot projects was a period of divisions, reorganizations, and bankruptcies resulting from the economic crisis of 1980 and the anomalies that affected much of the planting in the metropolitan region.

Oliveira Neto (2017) reports that in the 1980s, the oil palm Fatal Yellowing (AF) disease caused losses to Denpasa's plantations, causing apprehension among companies in the sector. In addition to the disease, between 1982 and 2000, economic instability and recession affected the transfer of federal funds to SUDAM, which, according to Homma (2016) and Oliveira Neto (2017), financed research and 
infrastructure, such as setting up palm oil factories and processing plants in 1976.

In 1974, Dendê do Pará Ltda. (Denpal) was the first company to change its corporate name becoming known as Denpasa, one of the forerunners of oil palm production in Pará. In this scenario of economic crisis and recession in investments in the Amazon, there was a split between the members of Agrícola Mista Paraense (Coodenpa) leading to the emergence of Dendê do Tauá Ltda (Dentauá).

Divisions and mergers continued between 1982 and 2000, when the agribusinesses Companhia Refinadora da Amazônia (Crai), Agropalma, Agropar, Amapalma, Companhia Palmares da Amazônia (Cpa), and Cia Refinadora da Amazônia became part of the Agropalma Group, the largest and most modern agro-industrial complex for planting, producing and processing oil palm in Brazil.

In 1989, the Cooperativa Agrícola Mista de Santa Izabel do Pará (Coomasi) was reformulated into the Companhia de Dendê Norte Paraense (Codenpa). In 1991, a group of entrepreneurs acquired Reflorestadora da Amazônia SA (Reasa), giving rise to Marborges SA, a company located in the municipality of Moju. (MULLER, FURLAN JR, FILHO, 2006; HOMMA, 2016). There were short-lived ventures such as Dendê Moema and Refinorte, which operated for eight and two years, respectively. Another project, Dendê da Amazônia SA (Denam), in São Domingos do Capim, was completely abandoned after planting due to the Fatal Yellowing disease (HOMMA, 2016; OLIVEIRA NETO, 2017).

Prior to the National Program for the Production and Use of Biodiesel (PNPB) and the Sustainable Oil Palm Program (PSOP), the Agropalma Group, Marborges, Dendetuá, and Denpasa boosted oil palm cultivation in the Tomé-açu Microregion, with products destined for the food industry. Based on these State policies, especially Decree $n^{\circ} 7,172$ (Brasil, 2010), which approved the agro-ecological zoning of oil palm cultivation, other companies also promoted production in the rural area of this micro-region.

Institutional conditions were created for oil palm farming in the rural area of Abaetetuba, driven by the companies Marborges, Guanfeng, Belém / Bioenergia / Brasil (BBB) / GALP, and Biopalma. The same occurred in Acará by Agropalma, BBB / GALP, Biopalma and Marborges; in Aurora do Pará by Biopalma; in Baião by BBB / GALP; in Barcarena by Biopalma; in Benevides by Denpasa; in Bonito by Mejer Agroflorestal Ltda; in Bujaru by BBB / GALP and Biopalma; in Cametá by BBB / GALP; in Capitão Poço by Marborges and ADM (Archer Daniels Midland); in Castanhal by Denpasa; in Concórdia do Pará by Biopalma / Dendetauá; in Garrafão do Norte by Marborges; in Igarapé-Açu by BBB / GALP and Palmasa; in Igarapé-miri by BBB / GALP and Biopalma; in Inhangapi by independent producers; in Ipixuna do Pará by the BBB; in Irituia by ADM; in Mãe do Rio by ADM and Biopalma; in Maracanã by ADM; in Mocajuba by BBB / GALP; in Moju by BBB / GALP, Agropalma, Biopalma, Marborges, Guanfeng do Brasil and WM Agroindustria Ltda; in Nova Timboteua by independent producers; in Santa Bárbara by Denpasa; in Santa Isabel by Yossan and Denpasa; in Santa Maria do Pará by independent producers; in Santo Antônio do Tauá by Dendetauá and Denpsa; in São Domingos do Capim BBB / GALP and ADM; in São Francisco do Pará by independent producers; in São Miguel do Guamá by ADM; in Tailândia by BBB / GALP, Agropalma and Biopalma; in Tomé-Açu by BBB / GALP and Biopalma; and in Vigia by Dendetauá (Map 1). 


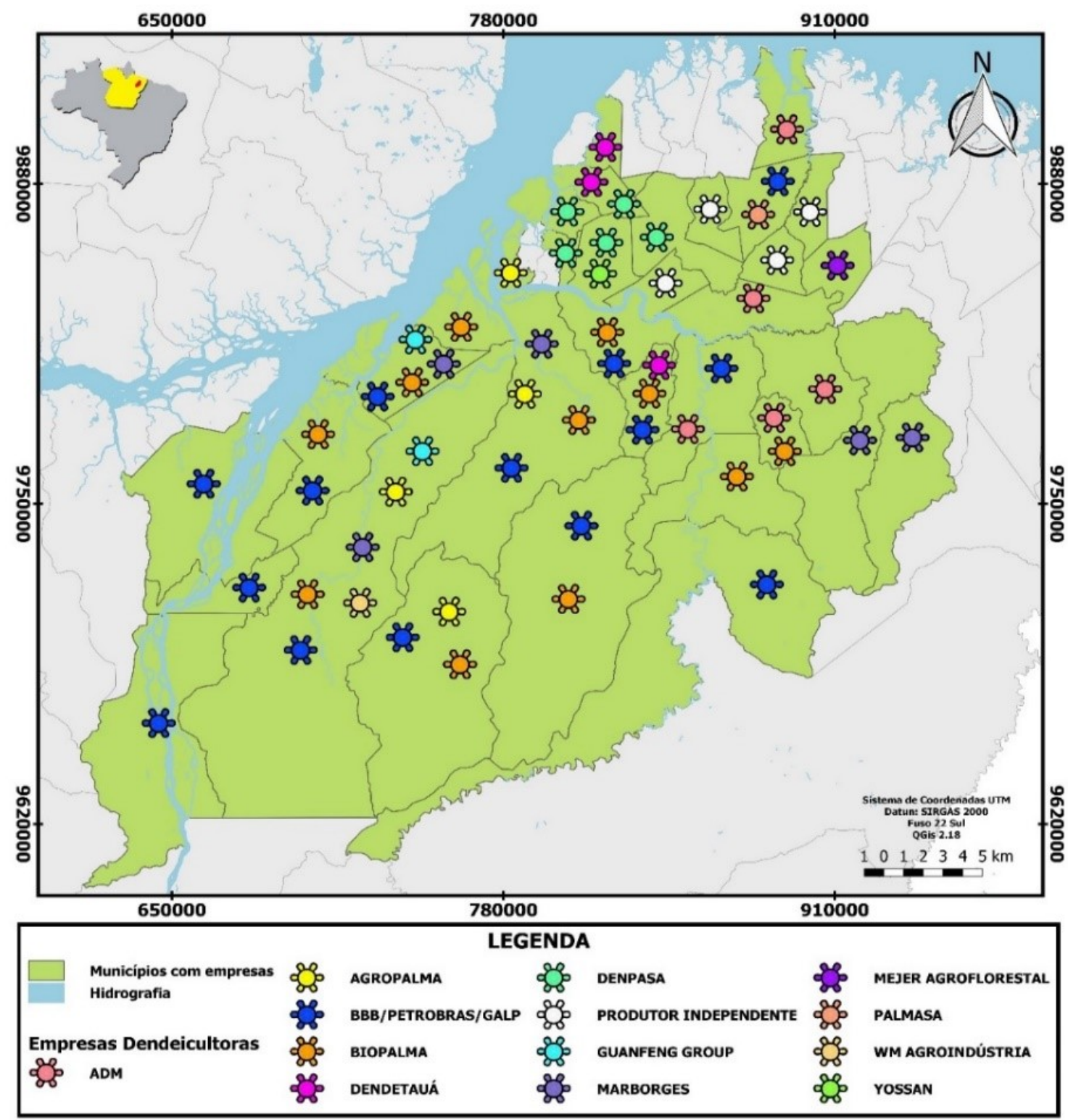

Map 1 - Oil palm companies in the state of Pará - 2019.Source: Fieldwork by the authors.

As shown in Table 1, these companies expanded the planting of oil palm in the state of Pará in relation to the state of Bahia, as well as increasing their contribution to Brazilian production. In the state of Pará, the area of oil palm clusters harvested rocketed from 38,912 thousand hectares in 2001 to 100,852 thousand hectares in 2018. The state of Bahia, the second-largest producer, with a similar area to Pará, actually surpassed the northern state in 2001 (Pará 38,912 and Bahia 45,663) and 2002 (Pará 36,612 and Bahia 41,690). 


\begin{tabular}{|c|c|c|c|}
\hline Year & Pará & Bahia & Brazil \\
\hline 2001 & 38.9 & 45.7 & 84.6 \\
\hline 2002 & 36.6 & 41.7 & 78.4 \\
\hline 2003 & 44.5 & 41.4 & 85.9 \\
\hline 2004 & 46.0 & 41.6 & 87.5 \\
\hline 2005 & 46.7 & 41.2 & 87.9 \\
\hline 2006 & 51.7 & 44.8 & 96.5 \\
\hline 2007 & 49.1 & 52.9 & 102.0 \\
\hline 2008 & 49.5 & 53.6 & 103.2 \\
\hline 2009 & 50.3 & 53.5 & 103.9 \\
\hline 2010 & 52.2 & 53.7 & 106.4 \\
\hline 2011 & 54.0 & 54.7 & 109.1 \\
\hline 2012 & 58.8 & 53.9 & 113.1 \\
\hline 2013 & 54.5 & 53.8 & 108.6 \\
\hline 2014 & 72,4 & 54.0 & 126,6 \\
\hline 2015 & 85.9 & 54.0 & 140.1 \\
\hline 2016 & 99.4 & 42.3 & 142.2 \\
\hline 2017 & 101.8 & 8.7 & 111.2 \\
\hline 2018 & 100.8 & 8.2 & 109 \\
\hline
\end{tabular}

Table 1 - Area of oil palm clusters harvested from Brazil, Pará and Bahia (in thousands of hectares)

-2001-2018. Source: https://www.embrapa.br/agropensa/producao-agricola-municipal . Access

29.01.2020. Organizers: João Santos Nahum; Leonardo de Sousa Santos; Cleison Bastos dos Santos.

Oil palm cultivation in the northeastern state was also above Pará's from 2008 to 2011. In 2012, Pará surpassed Bahia and in the period between 2013/2014 rose significantly, leaping from 54,475 thousand hectares (2013) to 72,375 thousand hectares in 2014. Since then, as graph 1 illustrates, compared to the state of Pará, production in the northeastern state declined, falling to 8,167 hectares in 2018, whereas Pará had 100,825. It is noteworthy that in 2018 the total harvested area of oil palm in Brazil was 109,044 thousand hectares.

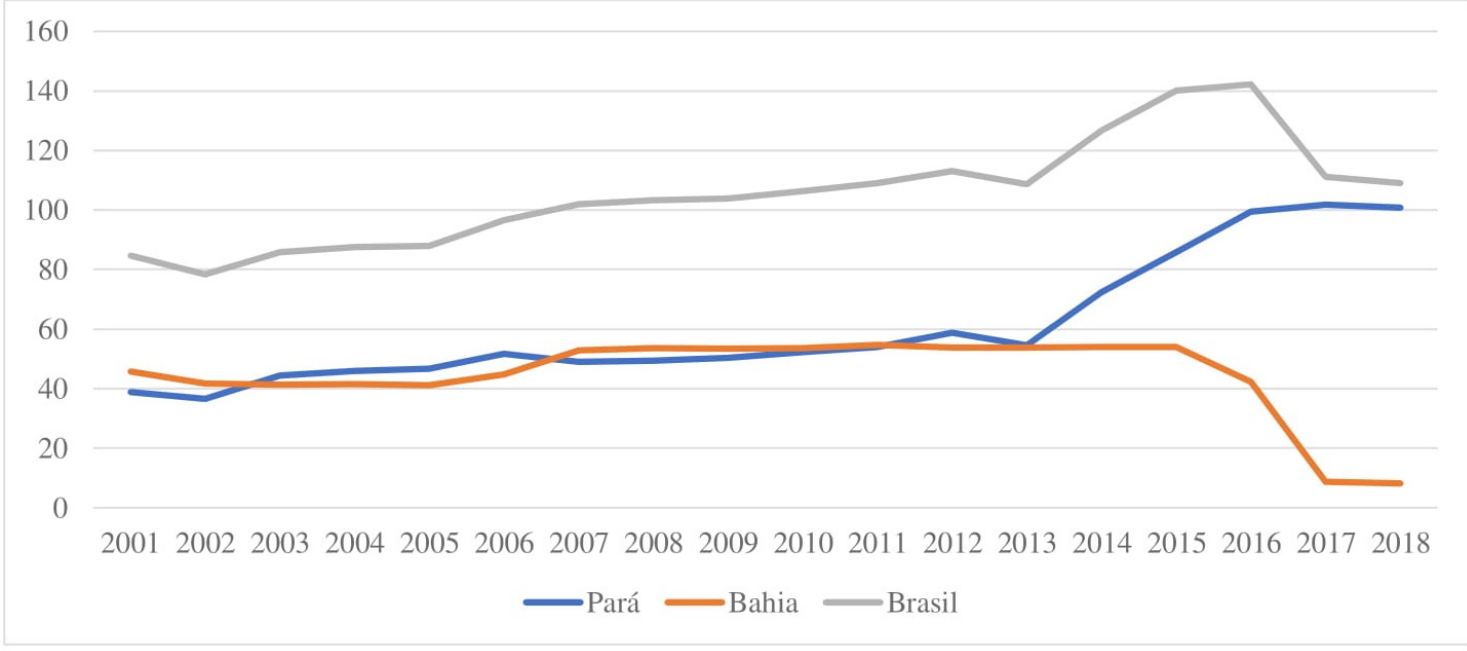

Figure 1 - The area of oil palm plantation in Brazil, Pará and Bahia from 2001 to 2016.Source: https://www.embrapa.br/agropensa/producao-agricola-municipal. Access: 01/29/2020. Organizers: João Santos Nahum; Leonardo de Sousa Santos; Cleison Bastos dos Santos. 
The graph shows that the expansion of oil palm in Brazil is due to increased cultivation in the states of Pará and Bahia, the first and second-largest areas in the country, respectively. It is significant that from 2013 to 2018 the Brazilian expansion of oil palm planting was due to the increase of this permanent crop in the state of Pará resulting from new ventures, a result of the policy of the Ministry of Agrarian Development (MDA) with the establishment of the PNPB and PSOP. Before the twenty-first century, although oil palm cultivation was associated with state action, we cannot consider it as a structuring event in the territorial dynamics of the places where it was located. It was not promoted directly by any ministry, instead, it was fostered in the Amazon by SPVEA and SUDAM, and the main financing agents were BASA, Banco do Estado do Pará and Banco do Brasil. However, it was still a timid state policy, a situation that changed after the implementation of the National Biodiesel Production and Use Program ( PNPB), created in 2004.

\section{POLICIES FOR OIL PALM CULTIVATION}

From the early pilot projects to January 2020, the time of writing, oil palm cultivation in the Amazon has been associated with state action, configuring itself as a State policy. During the first ten years (1940-1950) the crop entered the region in the context of the import substitution policies declared in a series of federal plans. In the following decade, specifically between 1963 and 1967, the federal government projected the concept of empty space, promoted the ideology of the agricultural frontier and encouraged the appropriation of land through large projects.

Nevertheless, in the areas where the large projects were established three and a half centuries ago, the land is part of the way of life of countless peoples and populations and is the main means of production. Raising animals, cultivation, extraction, and production follow the pace of cycles of the mineral, vegetable, and animal kingdoms. For three and a half centuries, the scarcity of information, communication, transport and energy systems in the region have fostered demographic dispersion, vitalizing the representation of the demographic void in the imaginary as if space and area were synonymous. The representation of the demographic void is associated with that of nature as a source of resources from the soil, subsoil, rivers, fauna and flora that should be used to generate employment, income, and social inclusion. The notion of the Amazonian frontier was divulged as a set of possibilities for the reproduction of capital. This was made possible under the authoritative command of the power bloc that took over the hegemony of the state structure after the 1964 civil-military coup.

In 1966, Operation Amazon reinvented the Amazon in the twentieth century, based on the State / Market / Capital tripod that promoted the depiction of nature in the Amazon as a source of resources, a demographically empty space with migrants playing the role of the workforce. The purpose of the Tripod was the reproduction of capital and it assigned a role to the region in the international division of labor. Large agricultural, mineral, road, and hydroelectric projects were the delineating vectors of the region's role as a supplier of raw materials to the world. To this end, technical systems were built in the form of road, energy, and communication networks, with large spatial prostheses such as highways, ports, airports, electrification, postal services, telephony, and telegraphs. The perspective was one of an empty, expanse of space; in short, synonymous with an opportunity crying out for investors and investments, attracted by the tax incentives regulated by SUDAM / BASA. These were the spatial conditions for the emergence of the technical environment and the agrarian period in the rural territorial formation of the Paraense Amazon, when the conflict between capital and peasants prevailed and land was the object of dispute, given that capital claims, expropriates and appropriates the land where the caboclo, riverine, quilombola or family farmers have lived for three and a half centuries, without ever worrying about land titles.

Agrarian space became marked by tensions, conflicts, and deaths in the production of the Amazonian space. Indigenous people, quilombolas, peasant farmers, extractivists, and trade unionists, among others, were killed, as indicated by the series of studies Conflitos no Campo no Brasil organized by the Pastoral Land Commission since 1985, the year in which 54 deaths were recorded in the countryside of the state of Pará (CPT, 1985). During this period, the State was overwhelmed by capital, which, in the name of modernization and the ideology of the agricultural frontier, left a deeply unequal and bloody agrarian structure in the Amazon. It took the slaughter of El Dourado de Carajás, on April 
17, 1996, broadcast worldwide by television networks for the State to establish a set of actions and policies for land ordering and regularization, as well as to appease conflicting interests.

It was under the aegis of the ideology of the agricultural frontier that in 1980 the State put forward the National Program for Vegetable Oils for Energy Purposes (Pro-Oil), the first state program for the cultivation of oil palm, which was not implemented. However, it was in the wake of state interest in this productive chain that the companies Cooamsi (1956), Denpal (1974), Coodempa and Coodenpa (1975), Denpasa and Coopama (1976), Denam and Reasa (1980), and Coacará and Agromendes (1981) were created (HOMMA, 2016).

From the management of SPVEA and then SUDAM, until the first decade of the twenty-first century, government programs encouraged this activity by associating it with food production or even the energy matrix, such as the National Program for the Production and Use of Biodiesel (PNPB) and the Program for Sustainable Palm Oil Production in Brazil (PSPO). The spatial basis of these programs was generated by the Agro-ecological Zoning of Oil Palm Cultivation (ZAE-Dendê), which set out the technical conditions for the expansion of the crop by defining the suitability of anthropized areas without environmental restrictions for the production and management of oil palm cultivation in the Amazon. This is because the annex to the decree indicated $23,276.73 \mathrm{~km}^{2}$ of preferential land for oil palm cultivation, distributed in 53 municipalities, and $69,999.88 \mathrm{~km}^{2}$ of regular land in 66 municipalities (BRASIL, 2010).

Another state policy that encouraged the cultivation of oil palm was the credit line offered by the National Program for Strengthening Family Agriculture (PRONAF), launched by the federal government with the objective of financing the integration of farmers into the oil palm production chain. For the ADM (s/d), the credit limit per beneficiary was R \$ 80,000.00 (eighty thousand reais) with an R\$ $8,000.00$ (eight thousand reais) limit per hectare and an interest rate of $2 \%$ pa (two percent per year). According to the technical project, the repayment term was up to 14 (fourteen) years, including a grace period of up to six years. The expansion of oil palm through the family farming project integrated small rural producers from the communities into the agribusiness chain (HOMMA, 2016). Nahum and Santos (2015) show that integrated farmers were from 15 municipalities and there were a total of 706 contracts, with Moju and Tomé-Açu having the highest number of contracts.

The incorporation of peasant farmers in the state of Pará into family farming programs with oil palm cultivation initially took place in the municipality of Moju, with the Arauai pilot project (Project I or Arauaí I), incorporating 50 families, in 2002. The project was coordinated by the Agropalma company and other government entities. In 2004, a further 50 families were incorporated by Project II or Project Soledade. In the same year, the federal government launched the National Program for the Production and Use of Biodiesel in Brazil (PNPB), in which family farmers are the main suppliers of raw material for the production of biodiesel. In this way, the PNPB fostered economic, social and environmentally sustainable development. This program also benefitted the oil palm companies, as participants in the program obtained the Social Fuel Seal that guaranteed reduced PIS / Pasep and Confins rates with reduction coefficients (BRASIL), 2004).

In 2005, again in Arauaí, fifty families from the community were selected to establish Project III or Arauaí II. In 2006, another 35 families took part in the Settlement Project (PA) Calmaria II (Project IV), associated with the Agropalma company. According to data from BASA (2014) apud Nahum and Santos (2015, p. 323), until 2006, there were 214 families integrated into the oil palm production chain in the state of Pará. In 2014, that is, eight years later, they totaled 1,590 (NAHUM; SANTOS, 2015). According to the Brazilian Association of Palm Oil Producers (ABRAPALMA), researcher Kátia Garcez, in the work Associativismo, cooperativismo, economia solidária e mercados institucionais nos municípios polo da cadeia da palma de óleo no Pará , found that in 2018 there were 1,800 families integrated with oil palm companies in 23 municipalities in the Northeast of Pará (ABRAPALMA, 2019).

For Nahum and Santos (2015), the oil palm boom gained strength with the new public policies, programs, and projects for territorial management and ordering in the decade of 2001. BASA's credit policy emerged specifically from the Northern Rural Constitutional Fund (FNO-rural), which invested an additional R\$ 10,500 million in Pará, between 1991 and 2001(ENRÍQUEZ; SILVA; CABRAL, 2003). Thus, based on the tripod of public or private investment, techniques and public policies, there 
was an expansion of oilseeds in the Amazon, especially in the Tomé-Açu Microregion, where Biopalma da Amazônia SA, Belém Bioenergia Brasil (BBB) and Archer Daniels Midland (ADM) of Brazil were present. The oil production figures in table 2 show the constant growth in the Brazilian sector.

\begin{tabular}{|c|cc|}
\hline Year & Palm oil production (thousand / ton.) & Growth Rate \\
\hline $\mathbf{2 0 0 1}$ & 118 & $7.27 \%$ \\
\hline $\mathbf{2 0 0 2}$ & 129 & $9.32 \%$ \\
\hline $\mathbf{2 0 0 3}$ & 142 & $10.08 \%$ \\
\hline $\mathbf{2 0 0 4}$ & 160 & $12.68 \%$ \\
\hline $\mathbf{2 0 0 5}$ & 170 & $6.25 \%$ \\
\hline $\mathbf{2 0 0 6}$ & 190 & $11.76 \%$ \\
\hline $\mathbf{2 0 0 7}$ & 210 & $10.53 \%$ \\
\hline $\mathbf{2 0 0 8}$ & 240 & $14.29 \%$ \\
\hline $\mathbf{2 0 0 9}$ & 250 & $4.17 \%$ \\
\hline $\mathbf{2 0 1 0}$ & 270 & $8.00 \%$ \\
\hline $\mathbf{2 0 1 1}$ & 310 & $14.81 \%$ \\
\hline $\mathbf{2 0 1 2}$ & 340 & $9.68 \%$ \\
\hline $\mathbf{2 0 1 3}$ & 370 & $8.82 \%$ \\
\hline $\mathbf{2 0 1 4}$ & 400 & $8.11 \%$ \\
\hline $\mathbf{2 0 1 5}$ & 415 & $3.75 \%$ \\
\hline $\mathbf{2 0 1 6}$ & 485 & $16.87 \%$ \\
\hline $\mathbf{2 0 1 7}$ & 500 & $3.09 \%$ \\
\hline $\mathbf{2 0 1 8}$ & 525 & $5.00 \%$ \\
\hline
\end{tabular}

Table 2 - Growth of oil palm production in Brazil - 2001-2018. Source: https://www.indexmundi.com/ . Accessed.01/29/2020 Organizers: João Santos Nahum; Leonardo de Sousa Santos; Cleison Bastos dos Santos.

Such an expansion would not have occurred without the State's participation and its financial, scientific, technological and infrastructure investment policies (NAHUM et al, 2015). Since the 1980s, study and research institutions such as EMBRAPA have participated in the country's efforts to obtain renewable sources of agro-energy (biogas and biofuel), through programs such as the National Energy Research Program (PNPE). Nowadays, there is a rise in partnerships between institutions, private companies and social groups (FURLAN JÚNIOR, et. al., 2006).

Environmental legislation states that planting must be in deforested and/or degraded areas in order to reduce pressure on native forests. Environmental conditions must be considered in the development of oil palm cultivation. However, the State does not provide the necessary human, technical and financial resources required to monitor the crop's spread in non-anthropized areas. In this spatial phenomenon's rationale, environmental impacts are externalities inherent to rural development. After all, the priority is to increase production and productivity, generate employment, income, and social inclusion through the professionalization of family farmers as producers of fresh oil palm fruit, even though the burden of this is the concentration of land (BACKHOUSE, 2013; NAHUM; SANTOS, 2013; SILVA, 2016), the monopolization of the use of water resources, the silting of springs (REPORTER BRASIL, 2013; NAHUM; SANTOS, 2013), as well as the risk to the production of traditional food crops, such as cassava (SANTOS, 2016; EDFRANKLIN; NAVEGANTES-ALVES, 2017; EDFRANKLIN; NAVEGANTES-ALVES, 2018, SANTOS, NAHUM, SANTOS, 2018).

\section{CONCLUSION}

The history of oil palm cultivation in the Amazon of Pará reveals the relationship between political actions and spatial reorganization. Being exogenous, oil palm cultivation needs two pillars: land and a workforce. All state action - from the arrival of the crop, the formation of companies, and the 
development of programs and policies - has aimed to create normative and spatial conditions for oil palm enterprises to obtain these two pillars of wealth.

Oil palm cultivation acts as a vector for rural territorial development in the places where it is found. It is single-mindedly perceived as a panacea for the structural problems that plague the rural environment and unevenly affect businessmen in the sector, peasants, family farmers, and even rural dwellers. Paving roads, expanding rural electrification, building bridges, ports, establishing telephone services, and transportation are among the actions that often accompany the arrival of new developments. This probably explains the rapid acceptance of this activity and its general spread in the Northeast Region of Pará.

The oil palm generates employment, income, and social inclusion. The integration of family farmers into the companies seems to solve some structural problems affecting the rural family productive unit, for example, the flow of production and the security in the purchase of crops. For all that, oil palm cultivation would not be part of state policy without first silencing opposition, especially from those that fight for the land and land reform. This is what happened in the first two decades of the twenty-first century, dominated by what Antunes (2018) calls the privilege of servitude that promotes the discourse of employability, income generation and inclusion in the consumer market as the raison d'être of rural life, although the price of wealth is the concentration of land ownership in a few companies, environmental impacts, risk to food production, and the region's subordination to the global food commodities market. However, the above are cynically interpreted by the business community as a necessary externality.

A manifestation of the relationship between politics and space, oil palm cultivation highlights the strong presence of representatives of agribusiness in the composition of the state power bloc. In fact, the formation of the Brazilian state is umbilically associated with the rentier nature of capital accumulation. This explains why the concentrated agrarian structure is a structural component of capital production and reproduction in Brazilian society. Without land concentration Brazilian capitalism would not exist and this concentration helps us to understand the silencing of the struggle for land, as stated by Martins (2003). Furthermore, it raises the hypothesis that agrarian reform will only occur when the concentrated land structure becomes an obstacle to the processes of production and reproduction of capital. However, this is still very far on the horizon, especially when the agribusiness sector is one of the main pillars of the national economy's export balance in the twenty-first century.

\section{REFERENCES}

ADM. Pronaf eco dendê. s/d. slides. Disponível em: https://www.sharp-partnership.org/RSS/ADM_PRONAF_Eco_Dende_en_Brasil.pdf. Acessado: 26/07/2019.

ANTUNES, R. O privilégio da servidão. O novo proletariado de serviços na era digital. São Paulo: Boitempo. 2018.

ASSOCIAÇÃO BRASILEIRA DE PRODUTORES DE ÓLEO DE PALMA. (ABRAPALMA), 2019. Disponível em: http://www.abrapalma.org/pt/reuniao-de-trabalhodocta/?fbclid=IwAR0s3RkI1Lo38_FEaD8quzut8c0ew UTZKq7fxseEYWSz9SdQy7wqj2LI9T0. Acesso em: 26 jul.2019.

BACKHOUSE, M. A desapropriação sustentável da Amazônia: o caso de investimentos em dendê no Pará: Fair Fuels? Working Paper 6, Berlim: 2013. Disponível em:https://www.fairfuels.de/data/user/Download/Ver\%C3\%B6ffentlichungen/FairFuelsWorking_Paper _6_Portuguese.pdf. Acesso em: 26 jul.2019.

BRASIL. Decreto $\mathrm{n}^{\circ}$. 7.172, de 7 de maio de 2010. Brasília/DF, 07/05/2010. Aprova o zoneamento agroecológico da cultura da palma de óleo e dispõe sobre o estabelecimento pelo Conselho Monetário Nacional de normas referentes às operações de financiamento ao segmento da palma de óleo, nos termos do zoneamento. Disponível em: http://www.planalto.gov.br/ccivil_03/_Ato2007-2010/2010/Decreto/D7172.htm. Acesso em: 26 
jul.2019.

BRASIL. Decreto n 5.297 de 6 de dezembro de 2004. Brasília, 6 de dezembro de 2004. Dispõe sobre os coeficientes de redução das alíquotas da Contribuição para o PIS/PASEP e da COFINS incidentes na produção e na comercialização de biodiesel, sobre os termos e as condições para a utilização das alíquotas diferenciadas, e dá outras providências. Disponível em: http://www.mda.gov.br/sitemda/secretaria/saf-biodiesel/o-selo-combust\%C3\%ADvel-social .Acesso em: 01 ago. 2019.

CARVAlHO, A. C. A de; NAHUM, J. S. Período do dendê na Amazônia paraense. Dendeicultura e dinâmicas territoriais do espaço agrário na Amazônia Paraense. Belém: GAPTA/UFPA. 2014.

CONDURU, J.M. P. Notas sumárias sobre a cultura do dendê na Amazônia. Belém, PA: Instituto Agronômico do Norte, 1957.

COSTA, E. J. M. Arranjos produtivos locais, políticas públicas e desenvolvimento regional. Brasília: Mais Gráfica Editora.2010.

CPT. Conflitos de terra no Brasil.1985. Disponível em: https://www.cptnacional.org.br/index.php/component/jdownloads/download/41-conflitos-no-campo-bras il-publicacao/266-conflitos-no-campo-brasil-1985 . Acessado: Acesso em: 29 jan.2020.

DARDOT, P; LAVAL, C. A nova razão do mundo. Ensaios sobre a sociedade neoliberal. São Paulo: Boitempo. 2016.

DIAS, C. L; DE SOUZA, R. L. Desenvolvimento de Plantações Satélites. Projeto Dendê. Secretaria de Estado de Agricultura, SAGRI, 1973.

EDFRANKLIN, M. S; NAVEGANTES-ALVES, Lívia F. Transformações nos sistemas de produção familiares diante a implantação do cultivo de dendê na Amazônia Oriental. Revista Desenvolvimento e Meio Ambiente, vol. 40, abril de 2017. Disponível em: https://revistas.ufpr.br/made/article/view/47330/32114. Acessado: Acesso em: 29 jan.2020.

EDFRANKLIN, M. S; NAVEGANTES-ALVES, Lívia F. Organização e diversidade dos sistemas de produção de agricultores familiares integrados à agroindústria de dendê no Nordeste paraense. Revista Brasileira de Gestão e Desenvolvimento Regional. v.14, n. 1, 2018. Disponível em: https://www.rbgdr.net/revista/index.php/rbgdr/article/view/3473. Acesso em: 29 jan.2020.

ENRÍQUEZ, G; SILVA, M. A da; CABRAL, E. Biodiversidade da Amazônia: Usos e potencialidades dos mais importantes produtos naturais do Pará. Belém: NUMA/UFPA. 2003.

FURLAN JÚNIOR, J.; KALTNER, F. J.; AZEVEDO, G. F.; CAMPOS, I. A. Biodiesel: Porque tem que ser dendê. Belém: Embrapa Amazônia Oriental, Palmasa; 2006.

FURLAN JÚNIOR, J.; MULLER, A. A. Agricultura familiar a dendeicultura na Amazônia. Belém: Embrapa Amazônia Oriental, 2004. (Recomendações Técnicas).

HOLANDA, S. B de. O extremo oeste. São Paulo: Editora Brasiliense. 1986.

HOMMA, A. K. Cronologia do Cultivo do dendezeiro na Amazônia. Embrapa Amazônia Oriental Belém, PA. 2016. Documentos. 423.

HOMMA, A. K. Histórico do desenvolvimento de híbridos interespecíficos entre caiaué e dendezeiro. Belém, PA: Embrapa Amazônia Oriental, 2016. 34 p. (Embrapa Amazônia Oriental. Documentos, 421).

HOMMA, A. K; FURLAN JÚNIOR, J. Desenvolvimento da dendeicultura na Amazônia: cronologia. In: MÜLLER, A. A.; FURLAN JÚNIOR, J. Agronegócio do dendê: uma alternativa social, econômica e ambiental para o desenvolvimento sustentável da Amazônia. Belém, PA: Embrapa Amazônia Oriental, 2001. p. 193-207. Disponível em: https://www.embrapa.br/web/mobile/publicacoes/-/publicacao/1056562/cronologia-do-cultivo-do-dende zeiro-na-amazonia . Acesso em: 26 jul.2019. 
IANNI, O. Ditadura e agricultura. O desenvolvimento do capitalismo na Amazônia: 1964-1978. 2ª Ed. Rio de Janeiro: Civilização brasileira. 1986.

LENÁ, P; OLIVEIRA, A. E. (Org.). Amazônia. A fronteira agrícola 20 anos depois. $2^{\text {a }}$ Ed. Belém: CEJUP/MPEG. 1992.

MARTINS, J de. S. O sujeito oculto. Ordem e transgressão na reforma agrária. UF

MECOR. Operação Amazônia (relatório ministerial apresentado à consideração do Senhor Presidente da República pelo Ministro Extraordinário para Coordenação dos Organismos Regionais). S/1. [196?]

MÜLLER, A. A. A cultura do dendê. Belém: Embrapa. 1980.

MÜlleR, A. A. MULleR, A. A. FURLAN JR. J. FILHO, P. C. A Embrapa Amazônia Oriental e o Agronegócio do dendê no Pará. Belém, PA: EMBRAPA-CPATU, 1997. 44 p. (Documentos, 257). Disponível em: https://www.infoteca.cnptia.embrapa.br/bitstream/doc/394940/1/Doc257.pdf. Acesso em: 29 jan.2020.

MÜLLER, A.A., ALVES R.M. A dendeicultura na Amazônia brasileira Embrapa Amazônia Oriental-Documentos (INFOTECA-E), $1997 . \quad$ Disponível em: https://www.infoteca.cnptia.embrapa.br/bitstream/doc/374987/1/CPATUDoc91.pdf . Acesso em 29 jan. 2020.

NAHUM, J. S. Região, discurso e representação: a Amazônia nos planos de desenvolvimento. Bol. geogr., Maringá, v. 29, n. 2, p. 17-31, 2011. Disponível em; http://www.periodicos.uem.br/ojs/index.php/BolGeogr/article/view/11001 Acessado: Acesso em: 29 jan.2010.

NAHUM, J. S; SANTOS, C. B. Impactos socioambientais da dendeicultura em Comunidades tradicionais na Amazônia paraense. ACTA Geográfica, Boa Vista, Ed. Esp. Geografia Agrária, 2013. Disponível em: http://revista.ufrr.br/index.php/actageo/issue/view/117/showToc. Acessado em Acesso em: 29 jan.2020.

NAHUM, J. S. Dendeicultura e Dinâmicas Territoriais do Espaço Agrário Na Amazônia Paraense. Clube de Autores, 2015.

NAHUM, J. S; SANTOS, C. B. O boom do dendê na microrregião de Tomé-Açu, na Amazônia paraense. Confins. Revue franco-brésilienne de géographie/Revista franco-brasilera de geografia, n. 25, 2015. Disponível em: https://journals.openedition.org/confins/10536. Acesso em: 29 jan.2020.

OLIVEIRA NETO, A. C. Territórios subordinados: análise da política de desenvolvimento territorial a partir da produção de óleo de palma pela Agropalma em assentamentos de reforma agrária no Pará. Tese de Doutorado apresentada ao Programa de Pós-Graduação em Geografia da Universidade Estadual Paulista Júlio de Mesquita Filho, 2017. Disponível em: https://repositorio.unesp.br/handle/11449/151496.Acesso em: 29 jan.2020.

PANDOLFO, C. A Cultura do Dendê na Amazônia. Belém SUDAM, 1981, 35p.

PROGRAMA NACIONAL DE PRODUÇÃO E USO DO BIODIESEL. Disponível em: http://www.mda.gov.br/sitemda/sites/sitemda/files/user_arquivos_64/Biodiesel_Book_final_Low_Comp leto.pdf. Acesso em: 26 jul.2019.

REPÓRTER BRASIL. Expansão do Dendê na Amazônia Brasileira. Elementos para uma análise dos impactos sobre a agricultura familiar no nordeste do Pará. São Paulo, 2013.Disponível em: http://reporterbrasil.org.br/documentos/Dende2013.pdf. Acesso em: 29 jan.2020.

SANTOS, C. B. dos Dendeicultura e Comunidades Camponesas da Amazônia Paraense. Clube de Autores, 2016.

SANTOS, C; NAHUM, J; SANTOS, L. Impactos da dendeicultura na produção de alimentos na Amazônia paraense: os agricultores integrados da Belém Bioenergia Brasil (BBB). Revista Pegada, v.19, n.3, 2018. Disponível em: http://revista.fct.unesp.br/index.php/pegada/article/view/6012. Acesso 
em: 29 jan.2020.

SUAREZ, P. A. Z.; MENEGHETTI, S. M. P. 70th anniversary of biodiesel in 2007: historical evolution and current situation in Brazil. Química Nova, v. 30, n. 8, p. 2068-2071, 2007. Disponível em: http://www.scielo.br/pdf/qn/v30n8/a47v30n8.pdf. Acesso em: 29 jan. 2020.

SILVA, F. L.; HOMMA, A. K. O.; PENA, H. W. A. O cultivo do DENDEZEIRO na Amazônia: promessa de um novo ciclo econômico na região. Embrapa Amazônia Oriental-Artigo em periódico indexado (ALICE), 2011. Disponível em: https://www.alice.cnptia.embrapa.br/handle/doc/950874 . Acesso em: 29 jan.2020.

SILVA, E. P. Agroestratégia e monocultura do dendê: a transferência silenciosa das terras da Reforma Agrária para o grande capital na Amazônia paraense. Dissertação (Mestrado) - Universidade Federal do Pará, Núcleo de Meio Ambiente (NUMA), Belém, 2016. (Disponível em: http://repositorio.ufpa.br/jspui/handle/2011/7630 . Acesso em: 29 jan.2020.

VILlELA, A. A. Expansão da palma na Amazônia Oriental para fins energéticos. 2014. 360 f. 2014. Tese de Doutorado. Tese (Doutorado)-Instituto Alberto Luiz Coimbra de Pós-Graduação e Pesquisa de Engenharia, Universidade Federal do Rio de Janeiro, RJ. Disponível em http://www.ppe.ufrj.br/images/publica\%C3\%A7\%C3\%B5es/doutorado/Alberto_Arruda_Villela.pdf . Acesso em: 29 jan.2020.

WILKINSON, J.; HERRERA, S. (2008). Os agrocombustíveis no Brasil. Quais perspectivas para o campo. 2008. Disponível em: $\mathrm{http}: / /$ www.observatoriodoagronegocio.com.br/page41/files/AgroCBRPerspectivasNov08.pdf. Acesso em: 20 jan.2020. 